\title{
Form of Narratives Used by Inexperienced Teachers in L2 Classroom Discourse
}

\author{
Vahid Rahmani DoQARUNI ${ }^{1, *}$, Hossein NAJJARI ${ }^{2}$ \\ ${ }^{1}$ University of Gonabad \\ ${ }^{2}$ University of Gonabad
}

\begin{abstract}
Despite the fact that the kinds of experiences that teachers have had might help us to understand why they hold the views they do, the presence and contribution of narratives of personal experience in second language classroom discourse has received little attention. In an effort to fill this gap in the field, this study focuses on the use of narratives of personal experience in English as a Foreign Language (EFL) classroom contexts by Iranian teachers to show what the form of their narratives are. This study is theoretically based on the constructionist theory of narrative analysis which deals with how narrative is produced. The present study is qualitative in nature in that it seeks to document, analyze, and interpret naturally occurring data in the EFL classroom settings. The participants were two EFL teachers, teaching general English courses in a private language institute in Babolsar, northern Iran. To collect the required data for this study, the first researcher observed the classrooms as a non-participant and made audio-recordings from three lessons of each teacher (resulting in 12 hours of naturally occurring data). The audio-recordings were then analyzed. In this way, the data were first transcribed and then the narratives in them were identified. Through an analysis of narratives of personal experience, this study has made a start at understanding the contribution such narratives make in an institutional context.
\end{abstract}

Keywords: teachers' narratives, EFL discourse, form of narratives, constructionist theory, qualitative study.

\section{Introduction}

Research in second/foreign language (L2) teacher education and development has seen increased advance and sophistication in the last two decades. There are now a large number of books and articles which deal with different dimensions of teacher education, and teacher behavior is looked at from professional, cognitive, social, as well as contextual perspectives (e.g., Bartels, 2005; Borg, 2003; Burns \& Richards, 2009; Gatbonton, 1999; Johnson, 2000, 2009; Richards \& Farrell, 2005; Richards \& Lockhart, 1994; Tedick, 2004; Tsui, 2003; Woods, 1996). With respect to the dominant model for teacher education in applied linguistics before the 1980s, such an enthusiasm in L2 teacher characteristics is relatively new (Akbari \& Tajik, 2009). That model was based on a process-product type where "the aim was to understand how teachers' actions led -or did not lead- to student learning" (Freeman, 2002, p. 2). The professional community has luckily expanded such simplistic interpretations of teaching and cognitive/social views of teaching have taken the place of behaviorist notions of instruction (Johnson, 2006). Considering this new belief, teaching is regarded as a complicated phenomenon in which "teachers are active, thinking decisionmakers who make instructional choices by drawing on complex, practically-oriented, personalized, and context-sensitive networks of knowledge, thoughts, and beliefs" (Borg, 2003, p. 81). Considering this recent trend, it is required to gain insights into the kinds of experiences that 
teachers have had which might help us to understand why they hold the views they do. One of the best ways which reveals such personal experiences is narratives (Levinson, 2006).

Insights gained from teachers' narrative analysis can enhance our understanding of teachers' behavior in the classroom context. This is because looking closely at talk can reveal general patterns of communication. Patterns in how teachers tell stories in different ways can illustrate how teachers behave in the general context of the classroom. Specifically, by targeting specific differences in discourse patterns of teachers, this research into narrative in classroom contexts is believed to be able to enhance teachers and researchers' mutual understanding. While the first benefit of studying teachers' narrative discourse analysis is to understand, generally, the communication differences, the second benefit of carrying out classroom discourse analysis is that researchers are best situated to study the localized and ever-changing discourse patterns specific to every teacher's own classroom. Needless to say, classroom application of the previous research findings is necessarily restricted to a certain place and time. Conducting classroom discourse analysis may or may not yield results similar to previous studies. But no matter what, the findings will facilitate classroom talk and learning. This brings us to the third reason time spent studying teachers' narrative discourse analysis pays off: When teachers understand multiple forms of talk in their classroom, institutional achievement improves. In other words, once teachers become aware of their different patterns of talk in the classroom, they are well-equipped to alter their teaching patterns in a way that encourage talk among students and improve classroom performance. Therefore, carefully studying interaction in teachers' talk inside the classroom and rearranging talk accordingly can lead to more productive and inclusive interactions - interactions likely to contribute to student success.

Despite such an importance, however, few studies, if any, have shed light on areas related to teachers' narratives inside the classroom context to help us understand their roles in L2 settings generally, and EFL contexts specifically. This paper is thus an attempt to fill the gap in the field of L2 teacher education.

\section{Literature review}

Since narrative discourse is integral to the way humans shape and show their understanding of knowledge and experience, it is widespread in most contexts dealing with social interaction. Brunner (1997), for example, contrasts and complements two modes of thought which seek to convince interlocutors: one is the logico-scientific mode which deals with general causes and their establishment, and the other is the narrative mode which seeks to validate experience through verisimilitude. Scholars have also emphasized on the role of narrative inquiry in educational research and practice (e.g., Clandinin, et al., 2007; Lyons \& LaBoskey, 2002; Rex \& Juzwik, 2011). Narrative has also been considered as a powerful method for capturing the complex processes of learning to teach (e.g., Doyle \& Carter, 2003; Richert, 2002). Moreover, it has been claimed that narratives "reveal how teachers engage in the construction of narratives about themselves in the context of their schools, classrooms, and communities, as well as the current political context of their teaching and learning to teach" (Schultz \& Ravitch, 2013, p. 37). As Olson and Craig (2009) argue, narratives can also illuminate the particular experiences of individuals. They contrast "small stories" with the grand "mega-narratives" in education and draw the attention to the importance of local and particularized stories that reside in the interactions between individuals, including teachers and students. The prevailing narratives of accountability and standardization, they suggest, often overshadow small stories. It has also been shown that teachers use narratives as a site of teacher knowledge to construct their own understandings of their profession (Craig, 2007; Rex, 2011). It is 
due to this importance that narrative analysis as a genre has gained its reputation as one of the major areas of inquiry within the broad field of discourse analysis (Thornborrow, 2012).

In contrast to a much wider body of work on teachers' narrative analysis research in general education, the studies dealing with this issue are surprisingly scarce in the field of applied linguistics and L2 education. Pishghadam and his colleagues (2013) examined the role of narrative intelligence in the success of English language teachers with respect to major and gender. Seven hundred and fifty three English language teachers and learners took part in their study. Scales of narrative intelligence and teacher success were used to gather data. The findings indicated that there existed a significant relationship between teachers' pedagogical effectiveness and their narrative intelligence. Moreover, EFL teachers who majored in English literature showed a higher level of narrative intelligence. In addition, there was no statistically significant difference between male and female teachers in terms of narrative intelligence. In another study, Fojkar and her colleagues (2013) reported the findings of a survey which was conducted among primary school English language teachers in Slovenia and aimed at revealing their attitudes toward the use of narratives in teaching English as a foreign language to children. The research results showed that most teachers used narratives when teaching English, generally once or twice per month, and that teachers who did not use a course book in the classroom employed storytelling or story reading techniques more frequently than teachers who followed a course book in their teaching. Despite the fact that the teachers participating in their study were aware of the importance of narratives in teaching English as a foreign language to young learners, they claimed that there was still a lot to be done concerning the selection of the narratives, the narrating techniques and the post-narration activities.

\section{3. esearch question}

As part of a larger research program, this study emerged from classroom observations conducted to document five EFL teachers' use of communication strategies in their talk (Rahmani Doqaruni, 2015). As teachers at the research site were visited, it was noticed that two inexperienced teachers were carrying out narrative quite differently in their classrooms in comparison to their experienced counterparts, despite using the same curriculum, materials, and resources. These two teachers used a large amount of narratives in contrast to their experienced colleagues who did not even use a single narrative in their talk. To examine this difference more closely, the following research question was proposed: What is the form of narratives carried out by inexperienced EFL teachers in their classrooms?

Although narrative is studied from various perspectives and approaches to narrative considerably vary (for a comprehensive review see Tomascikova, 2009), this study is theoretically based on the constructionist theory. In other words, this study deals with how narrative is produced (Threadgold, 2005).

\section{Methodology}

\subsection{The Qualitative Nature of the Study}

This study is qualitative in nature in that it seeks to document, analyze, and interpret naturally occurring data in the EFL classroom settings. For this reason, no attempt was made at manipulating variables or predicting performance. Research in the qualitative paradigm seeks to understand a phenomenon - here teachers' narratives - as it emerges dynamically and socially in the experiences of the participants (Marshall \& Rossman, 1999). A qualitative approach was adopted based on the 
initial observations of these classes and the differences that were perceived in the use of narratives in these classrooms. Qualitative research allowed us to explore and analyze closely the features of narratives and the effects of these features on the general classroom context.

Given the qualitative nature of the study, the findings may not directly generalize to all teachers in EFL classrooms. However, this study provides a close analysis of how narrative is carried out in one private language school in particular, and sheds light on the approach of narrative in general. The qualitative nature of this study precludes generalizing to all those who participate in EFL classes, although the analysis and findings might easily transfer to other settings and resonate with the reader. As is the case for all qualitative research, the findings of this study contribute to a grounded conceptual understanding of the construct of narrative structure rather than generalize the structure to all teachers and programs.

\subsection{Participants}

The participants were two EFL teachers, Bijan and Bahram (pseudonyms), teaching general English courses in a private language institute in Babolsar, northern Iran. Both teachers were male and were 24 and 23 years old. These two teachers are considered inexperienced as the literature in L2 teacher education has revealed that experienced teachers are those with many years of teaching behind them, with many interpreted in various studies as at least four to five years (e.g., Gatbonton, 1999; Tsui, 2003). Novice teachers in contrast are those who are still undergoing training, who have just completed their training, or who have just commenced teaching and still have very little (i.e. less than three years) experience behind them. Since Bijan and Bahram had less than three years of pedagogical practice, they were labeled as inexperienced in accordance with the previous literature. One class at pre-intermediate level was selected from each teacher. One class had 12 students and the other 14 students who were between 14 and 20. The classes met two times a week with 120minute sessions each time. Both teachers had completed their B.A degree in English language and gone through Teacher Training Courses in the language institute in which they were teaching. Both of them consented to taking part in the study.

\subsection{Data collection procedure}

According to Seedhouse (2004, p. 87), "classroom research has considered between five and ten lessons a reasonable database". This study rests on a corpus of six sessions (three sessions for each teacher) which is considered a reasonable sample size. To collect the required data for this study, one of the researchers observed the classrooms as a non-participant and made audiorecordings from three lessons of each teacher. A tape-recorder was used for making the audiorecordings of the whole class. An MP3 Player/Recorder was also put near to the teacher in each class both to record whole-class interaction and to capture teacher voice more clearly. Using the above-mentioned method, 12 hours of naturally occurring data was obtained from the two teachers participating in this study.

\subsection{Analysis of the data}

In order to find the answer to the research question, the audio-recordings of the classroom data were analyzed. In this way, the data were first transcribed and then the narratives in them were identified. As is typical in qualitative research, an inductive approach (Creswell, 2003; Dornyei, 2007) was adopted so that narratives emerged from the data. To begin, the entire corpus was read and narratives used by teachers were identified. Analysis of the data revealed a specific form of 
narrative which is presented in the following sections. The representative extract is a sample from all the narratives reflecting a particular narrative.

\section{Findings and discussion}

As Ruhlemann (2013, p. 24) mentions, "no attempt at defining conversational narrative would be complete without a discussion of the internal structure of narratives". A number of structural models have been proposed for narrative discourse such as the ones by Thorndyke (1977), and Longacre (1983). However, the most influential account of the internal structure of narrative is the one proposed by Labov. According to Labov (1972), narrative discourse falls into the following six narrative sections, of which the first (Abstract) and the last (Coda) are optional:

1) Abstract: summary (presents the plot in a nutshell)

2) Orientation: background (sets the scene for the listener)

3) Complication: main events (relates sequence of events)

4) Evaluation: point of the story (indicates why the story is told)

5) Resolution: result (relates how the events sort themselves out)

6) Coda: return to present (bridges the gap between narrated and narrating time)

All of the narratives identified in the data of the present study fall into this categorization. In order to clarify the issue, the following extract is dealt with in detail as an example. The other narratives can be analyzed in the same way.

As the following extract shows, number 1 acts as an abstract as it summarizes the whole story by making it clear that the narrator is going to talk about his worst moment in sport:

1 Teacher: what was your worst moment playing a sport?

From number 2 to 9 the teacher gives some background information which is consistent with the second phase of Labov's model that is orientation:

2 I can remember when I was in high school

3 we were playing soccer on cement

4 it wasn't grass it was cement and eh...

5 on the right side of the cement

$6 \quad$ it was damaged

$7 \quad$ it wasn't very soft ok?

8 It was broken

$9 \quad$ some holes all right?

From number 10 to 26 the teacher narrates the main event in a consequence of events which is in line with Labov's third phase that is complication:

10 Eh... Suddenly one of my friends tackled

11 eh... on the back of me yes

12 and I circled

13 and I felt on the cement 


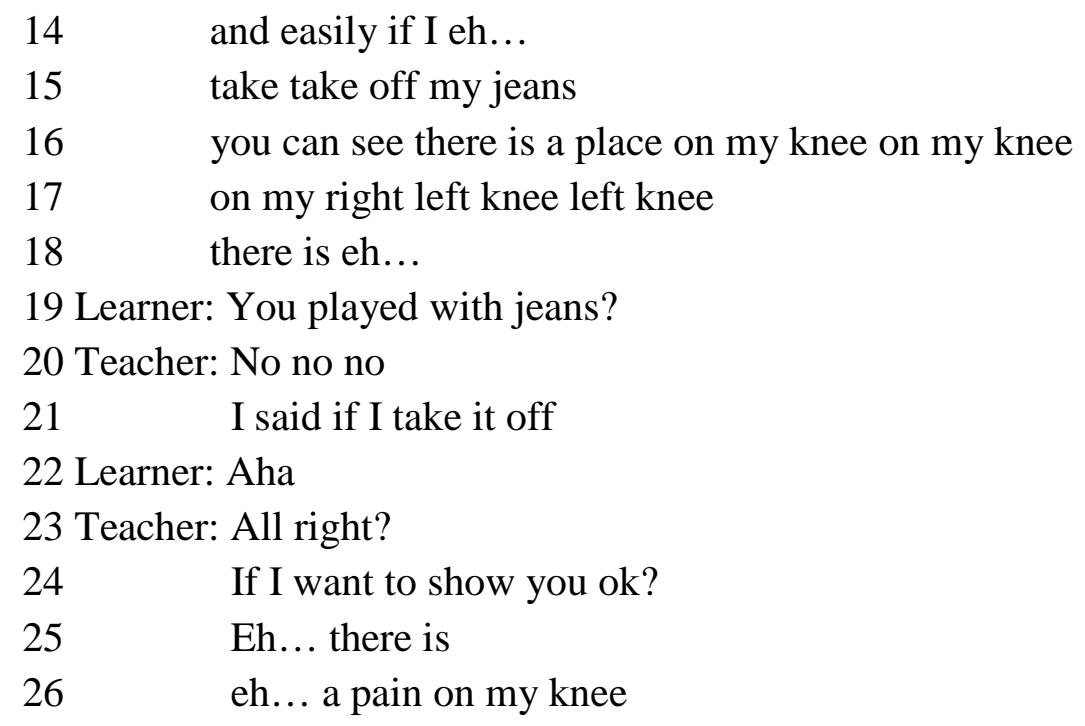

Number 27 is consistent with the fourth phase of Labov's model that is evaluation in which the narrator mentions why at all the narrative was told:

From number 28 to 41 the teacher talks about the consequences of the event which is in line with the fifth phase of Labov's model that is resolution:

$\begin{array}{ll}28 & \text { and I can remember } \\ 29 & \text { when I was in elementary school elementary school } \\ 30 & \text { Learner: Did you cry? } \\ 31 & \text { Teacher: No I didn't cry } \\ 32 & \text { I said ya Hossein } \\ 33 & \text { and all of the students laughed at me } \\ 34 & \text { are you in war? (the students laugh) } \\ 35 & \text { Just tackle } \\ 36 & \text { I tackled and you fell on the ground } \\ 37 & \text { and no it was very pain } \\ 38 & \text { and because eh... } \\ 39 & \text { my skeleton was visible } \\ 40 & \text { it means you could see my skeleton } \\ 41 & \text { yeah I mean my bone }\end{array}$

As it was mentioned earlier, the last phase that is coda, like the first phase that is abstract, is optional and it is not seen in this specific narrative.

\section{Conclusion}

In this study, the form of narratives in the context of second language education was examined. The discourse data from two inexperienced EFL teachers who were using the same curriculum and teaching in the same institute were analyzed. The insights gained from this analysis shed light on how narrative is realized in EFL classrooms. This study provides an additional piece 
of evidence on the achievement of a distinct teaching behavior by inexperienced teachers in comparison to their experienced counterparts.

In order to answer the research question, it was not started out with any hypothesis but only with an aim to explore. In this way, it was decided to try to approach the diverse and complex array of data with a pure mind, that is, without imposing any presuppositions on it. However, many more studies must be conducted to shed light on the effect of the use of narratives by teachers on students' progress, the main objective of the whole educational system generally, and EFL teaching profession specifically.

\section{References}

[1] Akbari, R., \& Tajik, L. (2009). L2 teachers' pedagogic knowledge base: A comparison between experienced and less experienced practitioners. Australian Journal of Teacher Education, 34 (6), 52-73.

[2] Bartels, N. (2005). Applied Linguistics and Language Teacher Education. New York: Springer.

[3] Borg, S. (2003). Teacher cognition in language teaching: A review of research on what language teachers think, know, believe, and do. Language Teaching, 36, 81-109.

[4] Brunner, J. (1997). The Culture of Education. Cambridge: Harvard University Press.

[5] Burns, A., \& Richards, J. C. (2009). The Cambridge Guide to Second Language Teacher Education. New York: Cambridge University Press.

[6] Clandinin, D. J., Pushor, D., \& Orr, A. M. (2007). Navigating sites for narrative inquiry. Journal of Teacher Education, 58 (1), 21-35.

[7] Craig, C. J. (2007). Story constellations: A narrative approach to contextualizing teachers' knowledge of school reform. Teaching and Teacher Education, 23 (2), 173-188.

[8] Creswell, J. (2003). Research design: Qualitative, quantitative, and mixed methods approaches. Thousand Oaks: Sage.

[9] Dornyei, Z. (2007). Research methods in applied linguistics: Quantitative, qualitative, and mixed methodologies. Oxford: Oxford University Press.

[10] Doyle, W., \& Carter, K. (2003). Narrative and learning to teach: Implications for the teachereducation curriculum. Journal of Curriculum Studies, 35(2), 129-137.

[11] Fojkar, M. D., Skela, J., \& Kovac, P. (2013). A study of the use of narratives in teaching English as a foreign language to young learners. English Language Teaching, 6 (6), 21-28.

[12] Freeman, D. (2002). The hidden side of the work: Teacher knowledge and learning to teach. Language Teaching, 35, 1-13.

[13] Gatbonton, E. (1999). Investigating experienced ESL teachers' pedagogical knowledge. Modern Language Journal, 83(1), 35-50.

[14] Johnson, K. E. (Ed.). (2000). Teacher Education. Alexandria: TESOL.

[15] Johnson, K. E. (2006). The sociocultural turn and its challenges for second language teacher education. TESOL Quarterly, 40, 235-257.

[16] Johnson, K. E. (2009). Second Language Teacher Education: A Sociocultural Perspective. New York: Routledge.

[17] Labov, W. (1972). Language in the Inner City. Oxford: Basil Blackwell.

[18] Levinson, R. (2006). The use of narrative in supporting the teaching socio-scientific issues: A study of teachers' reflections. Interaccoes, 4, 24-41.

[19] Longacre, R. E. (1983). The grammar of discourse. New York: Plenum Press. 
Bulletin de la Société Royale des Sciences de Liège, Vol. 86, special edition, 2017, p. 81 - 88

[20] Lyons, N., \& LaBoskey, V. K. (2002). Narrative inquiry in practice: Advancing the knowledge of teaching. New York: Teachers College Press.

[21] Marshall, C., \& Rossman, G. (1999). Designing Qualitative Research. Thousand Oaks: Sage.

[22] Olson, M. R., \& Craig, C. J. (2009). "Small" stories and meganarratives: Accountability in balance. Teachers College Record, 111 (2), 547-572.

[23] Pishghadam, R., Golparvar, S. E., \& Khajavy, G. H. (2013). The role of narrative intelligence in English language teaching, major and gender. Porta Linguarum, 19, 59-70.

[24] Rahmani Doqaruni, V. (2015). Communication strategies in experienced vs. inexperienced teachers' talk: A sign of transformation in teacher cognition. Innovation in Language Learning and Teaching, 9, 1-16.

[25] Rex, L. A. (2011). Narrative discourse analysis for teacher educators: Considering participation, difference, and ethics. In L. A. Rex \& M. M. Juzwik (Eds.), Narrative discourse analysis for teacher educators: Managing cultural differences in classrooms (pp. 1-29). New York: Hampton Press.

[26] Rex, L. A., \& Juzwik, M. M. (Eds.). (2011). Narrative discourse analysis for teacher educators: Managing cultural differences in classrooms. New York: Hampton Press.

[27] Richards, J. \& Farrell, T. (2005). Professional development for language teachers; strategies for teacher learning. Cambridge: Cambridge University Press.

[28] Richards, J. \& Lockhart, C. (1994). Reflective teaching in second language teaching classrooms. Cambridge: Cambridge University Press.

[29] Richert, A. E. (2002). Narratives that teach: Learning about teaching from the stories teachers tell. In N. Lyons \& V. K. LaBoskey (Eds.), Narrative inquiry in practice: Advancing the knowledge of teaching (pp. 48-62). New York: Teachers College Press.

[30] Ruhlemann, C. (2013). Narrative in English conversation: A corpus analysis of storytelling. Cambridge: Cambridge University Press.

[31] Schultz, K., \& Ravitch, S. M. (2013). Narratives of learning to teach: Taking on professional identities. Journal of Teacher Education, 64 (1), 35-46.

[32] Seedhouse, P. (2004). The Interactional Architecture of the Second Language Classroom: A Conversational Analysis Perspective. Oxford: Blackwell.

[33] Tedick, D. J. (Ed.). (2004). Second Language Teacher Education: International Perspectives. Mahwah: Lawrence Erlbaum.

[34] Thornborrow, J. (2012). Narrative analysis. In J. P. Gee \& M. Handford (Eds.), The Routledge Handbook of Discourse Analysis (pp. 51-65). New York: Routledge.

[35] Thorndyke, P. W. (1977). Cognitive structures in comprehension and memory of narrative discourse. Cognitive Psychology, 9, 77-110.

[36] Threadgold, T. (2005). Performing theories of narrative: Theorizing narrative performance. In J. Thornborrow \& J. Coates (Eds), The Sociolinguistics of Narrative (pp. 261-278). Philadelphia: John Benjamins.

[37] Tomascikova, S. (2009). Narrative theories and narrative discourse. Bulletin of the Transilvania University of Brasov, 2, 281-290.

[38] Tsui, A. B. (2003). Understanding expertise in teaching. New York: Cambridge University Press.

[39] Woods, D. (1996). Teacher cognition in language teaching. Cambridge: Cambridge University Press. 